\title{
Application of extrusion cooking technology in food industry
}

\author{
A.A. SAWANT*, N.J. ThaKOR and S.B. SWAMI
}

Department of Agricultural Process Engineering, College of Agricultural Engineering and Technology, Dr. Balasaheb Sawant Konkan Krishi Vidyapeeth, Dapoli, RATNAGIRI (M.S.) INDIA

Email : abhi52@rediffmail.com; abhimanavi@gmail.com

*Author for Correspondence

Research chronicle : Received : 22.04.2015; Accepted : 29.11.2015

\section{SUMMARY :}

Snack foods are being considered integral part of human food habits and they become more relevant if targeted to satisfy the need. The promising feature of the technology is that the final product can be tailored as per nutrition requirement by changing the feed material composition. The concern of the present time to prepare such food products which can be aid in control prevailing diseases like heat problems, diabetics, blood pressure etc. extrusion cooking is a feasible technique to manufacture expanded products and has been the objects of studies to enhance the nutrition and functional properties of extrudates for the development of various product. Extrusion cooking results in starch gelatinization, denaturation of proteins, inactivation of many native enzymes and antinutritional factors, reduction of microbial counts and improvements in digestibility and biological value of proteins. Extruded product can be categorized for a particular application depending on their functional properties such as water absorption and water solubility indexes, expansion ratio, bulk density and viscosity of the dough.

\section{KEY WORDS : Application, Extrusion, Cooking technology, Food industry}

How to cite this paper : Sawant, A.A., Thakor, N.J. and Swami, S.B. (2015). Application of extrusion cooking technology in food industry. Internat. J. Proc. \& Post Harvest Technol., 6 (2) : 177-183. 